\title{
Length-weight relationships for 30 fish species caught in coastal waters of Veracruz, western Gulf of Mexico
}

\author{
Relaciones de longitud-peso para 30 especies de peces capturadas en \\ aguas costeras de Veracruz, Oeste del Golfo de México
}

\author{
Gabriela Galindo-Cortes ${ }^{1}$, César Meiners ${ }^{1}$ and Lourdes Jiménez-Badillo ${ }^{1}$
}

\begin{abstract}
${ }^{1}$ Instituto de Ciencias Marinas y Pesquerías, Universidad Veracruzana, Hidalgo 617, Col. Río Jamapa, 94290, Boca del Rio, Veracruz, México.gagalindo@uv.mx

Abstract.- Length-weight relationships were calculated for 30 fish species belonging to 14 families using 2562 specimens caught in coastal waters of the western Gulf of Mexico. The number of fish measured varied by species, ranging from 32 individuals for Polydactylus octonemus to 177 for Anchoa hepsetus. Most of the values of the parameter $b$ are within expected range of 2.5-3.5. The effects of sex for some of these species were taken into account; however, none of them had significantly different. The results of this study provide useful basic biological information about the most conspicuous species of fish caught in the study area.
\end{abstract}

Key words: Coastal fishes, fish assemblages, length-weight relationship

\section{INTRODUCTION}

The relationship between body length and weight is relevant for fishery biology in several topics related with stock and population assessments such as biomass estimates obtained from age- and length-structured models (Pope 1972, Methot 1989), which require the calculation of mean weight of individuals per age or length class through the length-weight relationship (LWR). Furthermore, LWR is useful to calculate fish condition and provides information about life history and morphological comparisons between different fish species or between different fish populations from different habitats (Petrakis \& Stergiou 1995, Koutrakis \& Tsikliras 2003, Froese 2006).

This contribution takes importance because the study area, known as Las Barrancas, is neighbor to the south of Veracruz Coral Reef System National Park, which was decreed as a marine protected area in 1992, and it could be impacted in the short-term by human activities related to port expansion in order to increase capabilities for commercial activities. Despite its importance, basic biological information about fish species and its interactions with other living resources in the area of influence of the Park is still scarce or unpublished. This study, therefore, aims to present fish diversity, size ranges, and provides the first LWR reference for 30 fish species in coastal waters of Veracruz, western Gulf of Mexico.

\section{Materials AND METHODS}

The specimens of fish species were collected from 16 fishing samplings carried out during September 2009 to October 2012 in a shallow sandy beach called 'Las Barrancas' and located at $18^{\circ} 59^{\prime} 43.83$ ' N, 95 $57^{\circ} 53.78^{\prime \prime} \mathrm{W}$ ( $8 \mathrm{~km}$ southward of the Veracruz Reef System) (Fig. 1). Each sampling consisted of a single fishing haul with a beach seine net of $750 \mathrm{~m}$ long, $3 \mathrm{~m}$ high, mesh size 31/2" at lateral wings and $3 / 4$ " at the cod-end. Once each fishing haul was concluded, the total catch was separated and identified at the species level, a subsample was used for biometrics. The scientific name for each species was checked according to Froese \& Pauly (2013).

Total length (L) of each fish was measured to nearest $0.1 \mathrm{~cm}$, and the individual total weight $(\mathrm{W})$ recorded to nearest $0.1 \mathrm{~g}$. Sex was determined in some cases by macroscopic analysis of the gonads, otherwise it was registered as indeterminate sex. We applied a power function (Huxley 1932, Le Cren 1951), $\mathrm{W}=a \mathrm{~L}^{b}$, where $a$, is the intercept (initial growth coefficient or condition factor) and $b$ the slope (growth coefficient, i.e., fish relative growth rate). $W$ and $L$ were $\log$ transformed and the resulting linear relationship fitted by the least squares regression using $\mathrm{W}$ as the dependent variable (Le Cren 1951, Ricker 1975). The degree of association between the variables was computed by the determination coefficient $\left(r^{2}\right)$. The Cook's distance was helpful to identify 


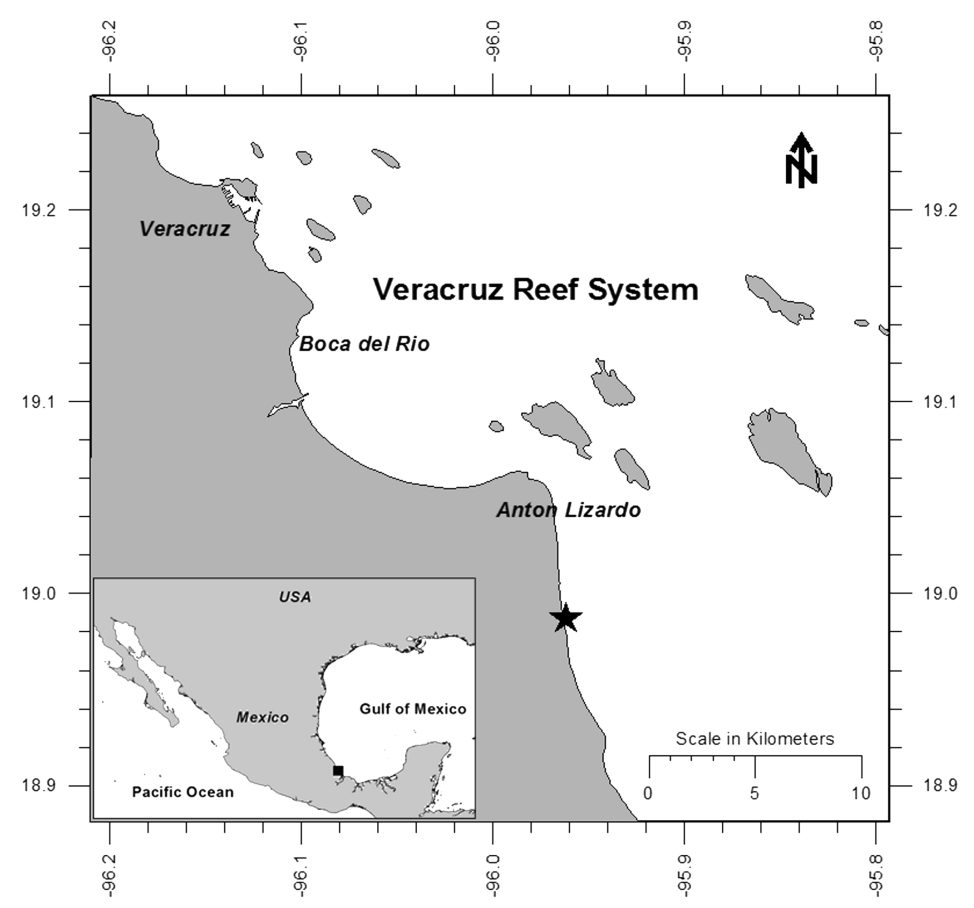

Figure 1. Study area sandy beach Las Barrancas showing sampling area at western of Gulf of Mexico ( $\star$ ), and the Veracruz Coral Reef System inside the National Park / Área de estudio en playa arenosa Las Barrancas indicando el sitio de muestreo en el oeste del Golfo de México $(\star)$ y el Sistema Arrecifal Veracruzano dentro del Parque Nacional

the most influential observation in data sets (Cook 1977). When the sample size by sex was sufficient $(\mathrm{n} \geq 30$ for each sex), length-weight relationships were calculated separately; and data from juveniles of indeterminate sex were added in both length-weight relationship regressions for females and males. To test the hypothesis of isometric growth, $\mathrm{H}_{\mathrm{o}}: b=3$ vs $\mathrm{H}_{1}: b \neq 3$, a special case of the Wald (F-distribution) test was used (Seber \& Wild 1989). This is based on an $F$ test with 1 degree of freedom of the numerator and $n-k$ parameter degrees of freedom of the denominator. The test is rejected with a significance level ( $\alpha$ ) of 0.05 if $\hat{F}>F_{k n-k}^{\alpha}$. In the same manner, to determine if there are significant differences between the male and female values of $b$ was tested if $\mathrm{H}_{\mathrm{o}}: b_{\text {males }}-b_{\text {females }}=0$, which indicates that there is no difference between slopes, vs. $\mathrm{H}_{1}: b_{\text {males }}-b_{\text {females }} \neq 0$, indicating differences in the value of $b$. In all cases, Ho is rejected if $P<0.05$. Statistics were performed using the STATA software version 13.0.

\section{RESUltS AND DISCUSSION}

A total of 2562 individuals from 30 fish species belonging to 14 families were examined. The taxa examined in this study included species covering a wide array of body shapes and life history strategies. Carangidae was the most important family in terms of abundance and species richness. The number of fish measured varied by species, ranging from 32 individuals for Polydactylus octonemus to 177 for Anchoa hepsetus.

Table 1 shows the sample size, length range, LWR parameters $(a$ and $b$ ) for each fish species and its statistical values. Linear regressions fitted to estimate the LWR were significant for all species. Values of parameters $b$ vary from 2.525 for Hyporhamphus unifasciatus to 3.597 for Cetengraulis edentulus. Most of the $b$ values ranged for $2.5<\mathrm{b}<3.5$ as suggested Carlander (1969), except to C. edentulus. For 11 species the $b$ values showed an isometric growth. A positive allometry growth was detected for 14 fish species $(b>3)$, while only for 5 species had negative allometry growth $(b<3)$. Seven species had a sample size enough to applied length-weight regressions by $\operatorname{sex}$ ( $n \geq 30$ for each sex); however no significant differences in slopes were observed. 


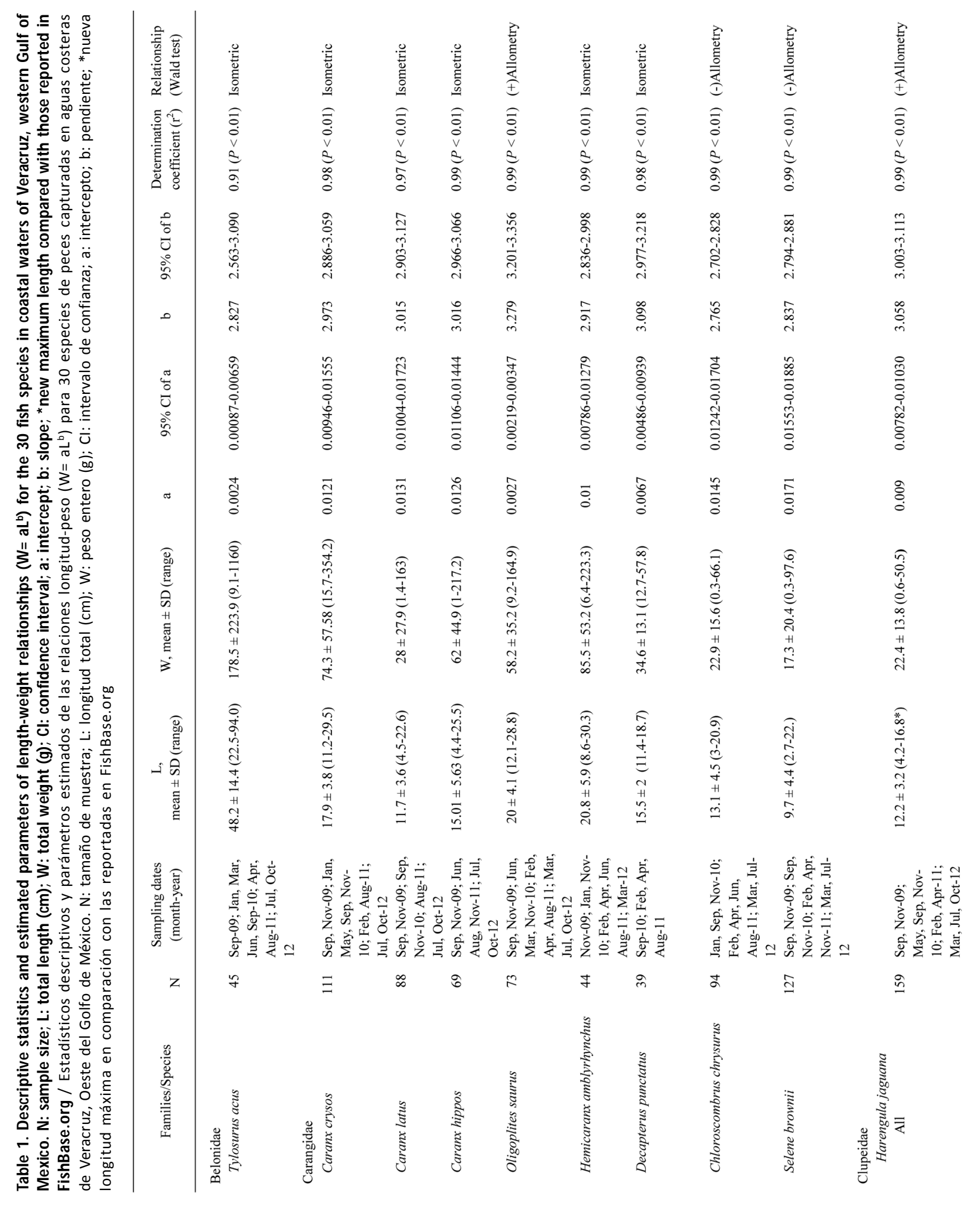

Vol. 50, № 1, 2015 - 143 


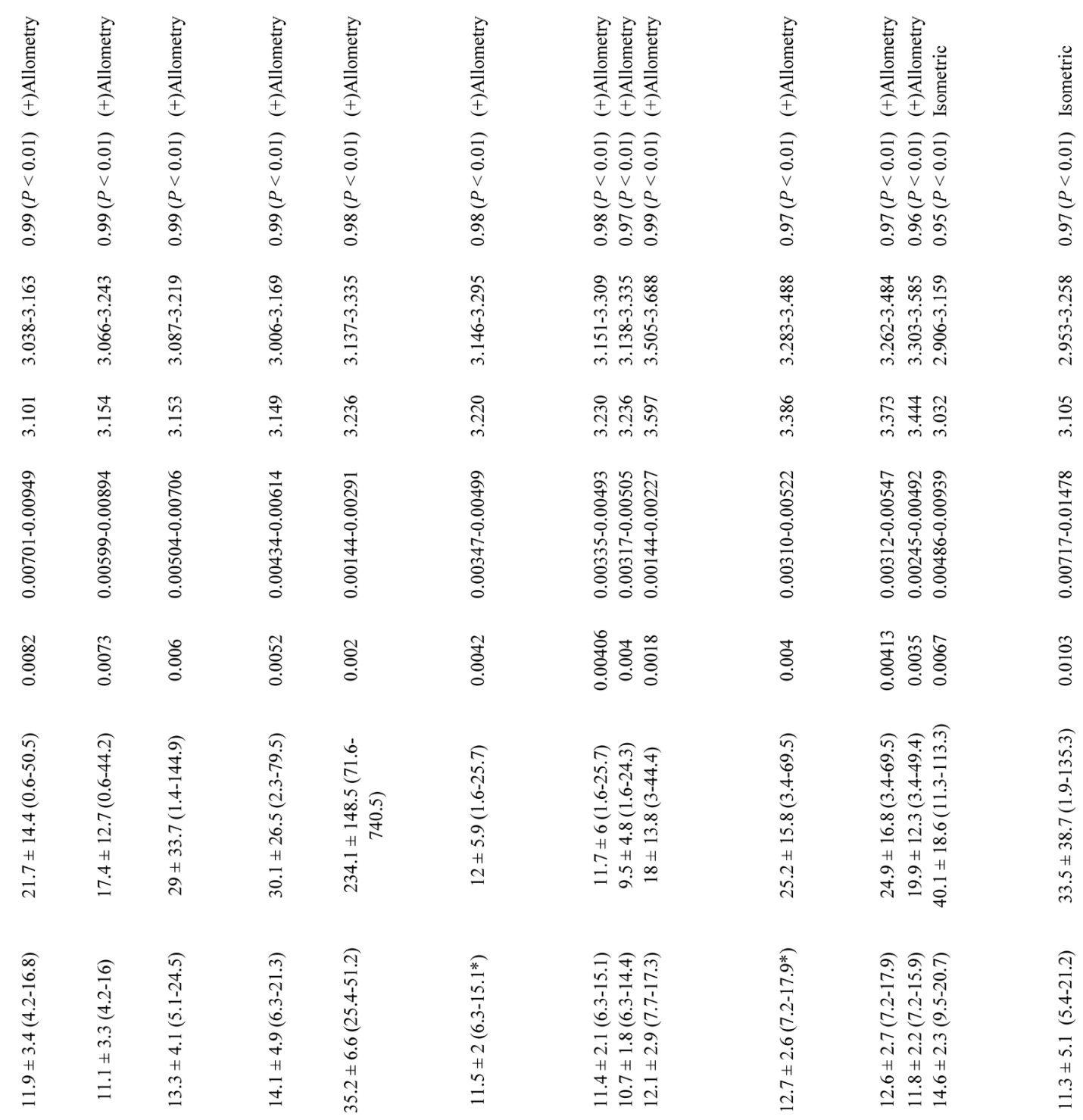

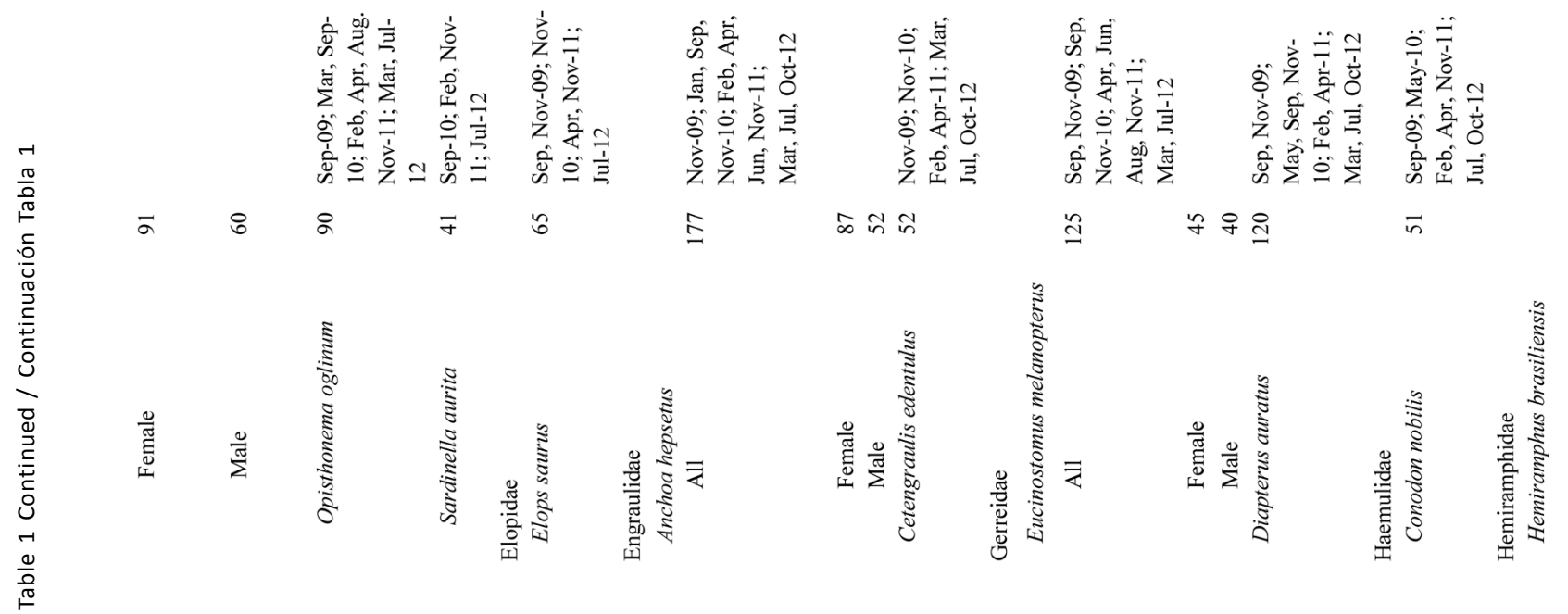




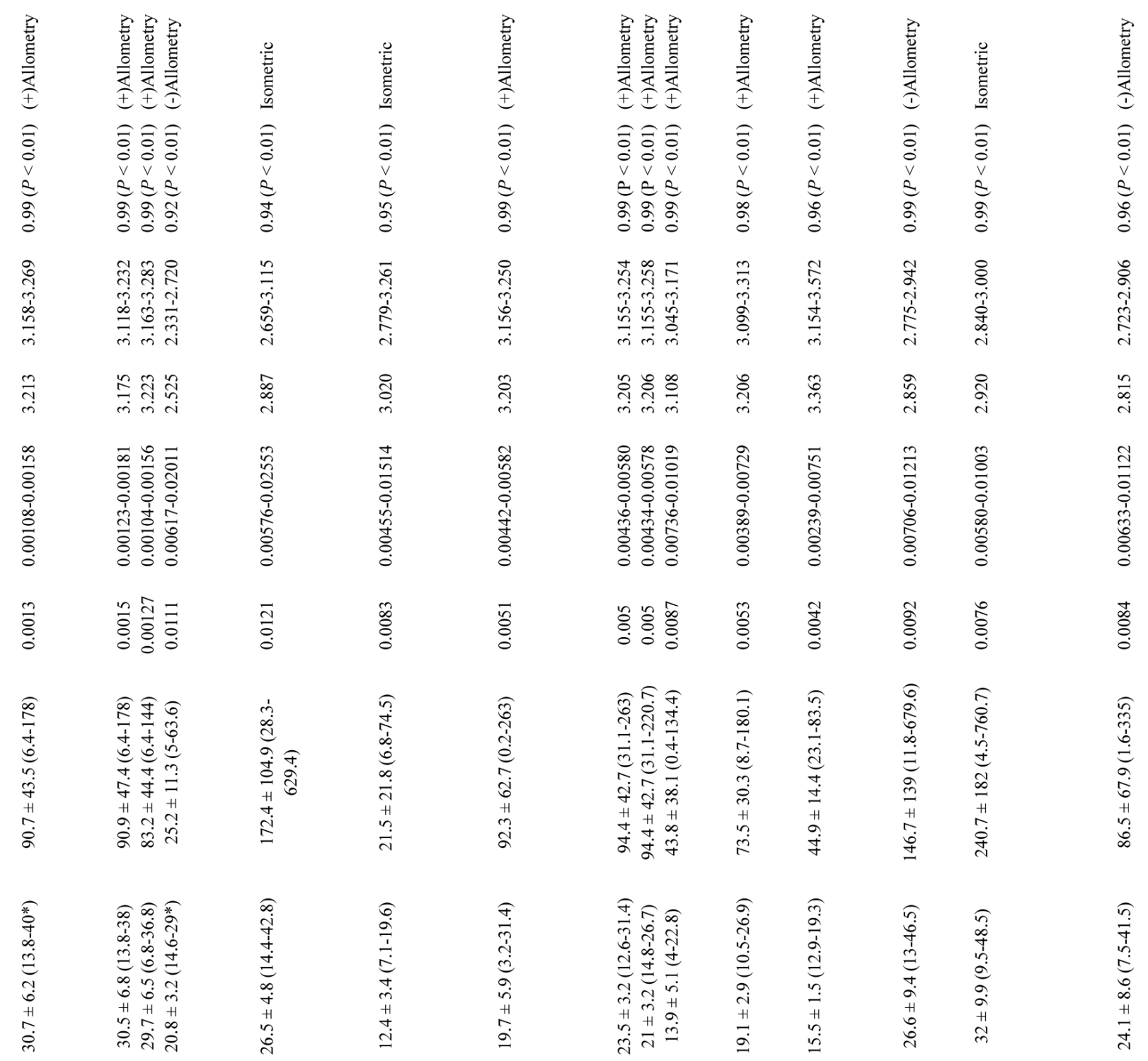

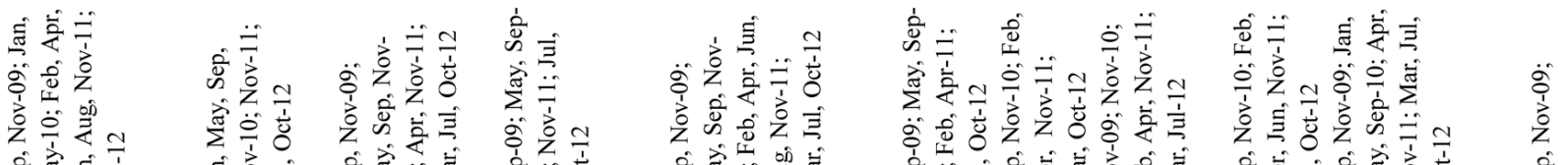

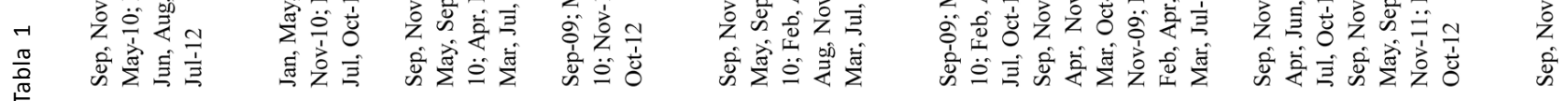

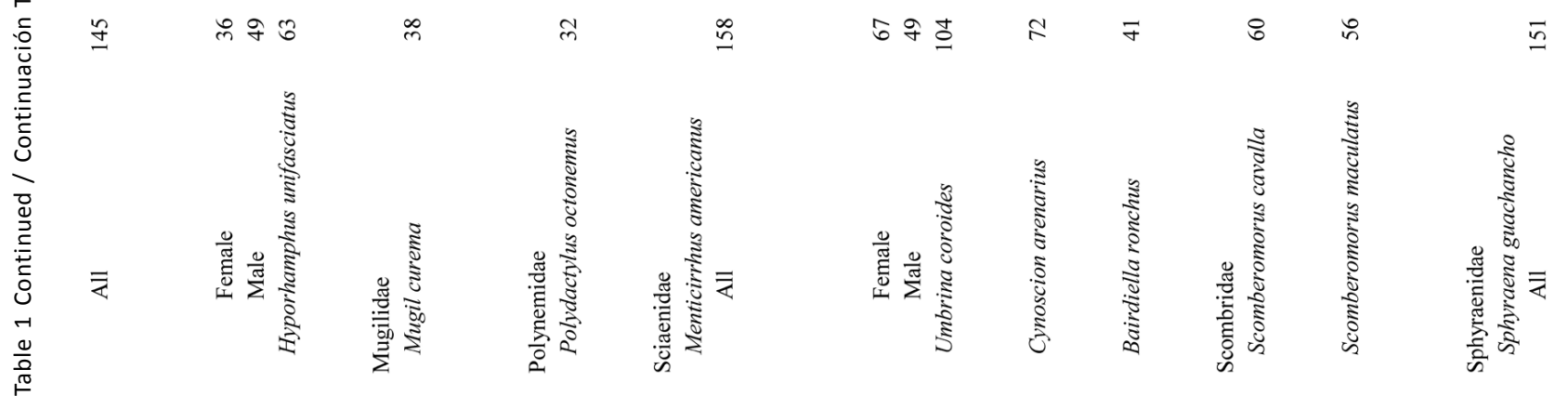




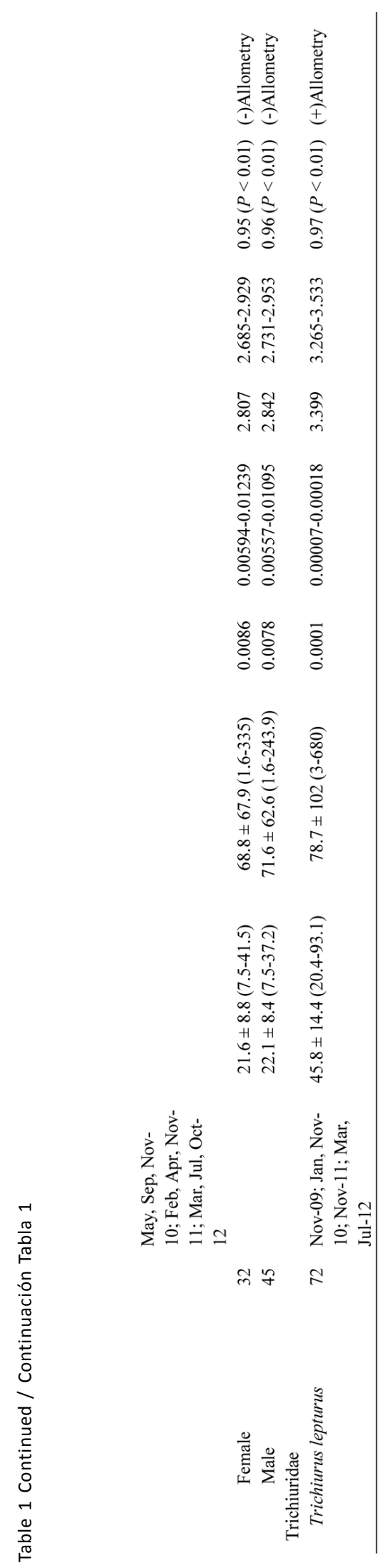

146 Galindo-Cortes et al.

Length-weight relationship of coastal fish species 
No information on LWR of the selected fish species was available for the study area. However, it is possible comparing our findings against estimations from other areas reported in FishBase (Froese \& Pauly 2013). Taking this into account, the LWR parameters of this study were within the ranges reported in the literature for the most fish species but lower for Tylosurus acus and $H$. unifasciatus, and higher for Cynoscion arenarius, Eucinostomus melanopterus, Oligoplites saurus and $P$. octonemus.

It is well known that the functional regression $b$, value varies according to the body shape of fish and some life history parameters such as maturity, maximum size, growth rate, and others factors like habitat, stomach fullness, health, sex, age, etc., (Ricker 1975, Froese 2006).

According to Froese et al. (2011) an adequate sample size of about 100 specimens per species, i.e., there is no need to kill thousands of specimens only for WLR estimates with exception of rare and endangered species as well as specimens that were caught from opportunity sampling.

The results of this study provide useful basic biological information about the most conspicuous species of fish caught in the study area that can also be compared to surrounding areas, like the Veracruz Coral Reef System National Park.

\section{ACKNOWLEDGMENTS}

We appreciate the assistance of the fisher folks in the study area, commanded by Don Lomo and several students who brought invaluable assistance during the field work: Tanit Duran-Parra, Luis Mier-Uco, Juan Pablo Bouchot-Alegria, Teresita Alacaraz-García and Alejandro Roldán-Heredia. This work was partially funded by the Mexican Ministry of Public Education (SEP) through project PROMEP. The first author has financial support of Consejo Nacional de Ciencia y Tecnología (Grant no. CONACYT I0007-2013-01-203528).

\section{LITERATURE CITED}

Carlander KD. 1969. Handbook of freshwater fish biology, 752 pp. Iowa University Press, Iowa.

Cook R. 1977. Detection of influential observation in linear regression. Technometrics 19: 15-18.

Froese R. 2006. Cube law, condition factor and weight-length relationships: history, meta-analysis and recommendations. Journal of Applied Ichthyology 22: 241-253.

Froese R \& D Pauly. 2013. FishBase. <http://fishbase.org>

Froese R, AC Tsikliras \& KI Stergiou. 2011. Editorial note on weight-length relations of fishes. Acta Ichthyologica Et Piscatoria 41(4): 261-263.

Huxley JS. 1932. Problems of relative growth, $276 \mathrm{pp}$. Methuen \& Co., London.

Koutrakis ET \& AC Tsikliras. 2003. Length-weight relationships of fishes from three northern Aegean estuarine systems (Greece). Journal of Applied Ichthyology 19: 258260.

Le Cren ED. 1951. The length-weight relationship and seasonal cycle in gonad weight and condition in the perch (Perca fluviatilis). Journal of Animal Ecology 20(2): 201-219.

Methot D. 1989. Synthetic estimates of historical abundance and mortality for Northern Anchovy. American Fisheries Society Symposium 6: 66-82.

Petrakis G \& KL Stergiou. 1995. Weight-length relationships for 33 fish species in Greek waters. Fisheries Research 21: 465-469.

Pope J. 1972. An investigation of accuracy of Virtual Population Analysis using Cohort Analysis. International Commission for the Northwest Atlantic Fisheries Research Bulletin 9: 65-74.

Ricker W. 1975. Computation and interpretation of biological statistics of fish population. Bulletin of the Fisheries Research Board of Canada 191: 1-382.

Seber GAF \& CJ Wild. 1989. Nonlinear regression, 768 pp. Wiley, New York. 